\title{
ILLUMINATING STUDENTS' UNDERSTANDING AND ACCEPTANCE TOWARDS THE DUAL LANGUAGE PROGRAMME (DLP)
}

\author{
Ashairi Suliman, Mohamed Yusoff Mohd Nor, Melor Md Yunus* \\ Universiti Kebangsaan Malaysia, Malaysia \\ *e-mail: melor@ukm.edu.my
}

\begin{abstract}
The Dual Language Programme (DLP) is an initiative introduced by the Ministry of Education to advocate the teaching and learning of science and mathematics in the English language. Resembling the previous educational policy named PPSMI, this programme commenced in 2016, offering the flexibility for English to be used as the instructional medium for the two subjects. After four years of its inception, it is crucial to discover the programme's acceptance among those involved directly with the programme. Thus, this study expounds students' understanding and acceptance of the programme by investigating the influence of age, gender, locality and the type of school on their understanding and acceptance of DLP. This study involved 2162 students, and it was found that their understanding and acceptance level of the programme are at a moderately high level. The findings also revealed a significant difference between the acceptance of the programme. As an alternative to solidify the English mastery, the implementation of DLP needs to be improved for it to be well-accepted by interest groups.
\end{abstract}

\section{Keywords: Dual Language Programme, students, education, programme acceptance}

\section{PENYEBAB PEMAHAMAN DAN PENERIMAAN SISWA TERHADAP PROGRAM DWI BAHASA (DLP)}

\begin{abstract}
Abstrak: Program Dwi Bahasa (DLP) adalah inisiatif yang diperkenalkan oleh menteri pendidikan untuk menganjurkan pengajaran dan pembelajaran sains dan matematika dalam bahasa Inggris. Program ini menyerupai kebijakan pendidikan sebelumnya yang bernama PPSMI, program ini dimulai pada tahun 2016, menawarkan fleksibilitas bahasa Inggris untuk digunakan sebagai media pembelajaran untuk dua mata pelajaran. Setelah empat tahun sejak awal diperkenalkan, penting untuk mengetahui penerimaan program dalam kalangan mereka yang terlibat secara langsung dengan program tersebut. Jadi, penelitian ini menjelaskan secara terperinci pemahaman dan penerimaan siswa terhadap program ini dengan meneliti pengaruh usia, jenis kelamin, lokalitas dan jenis sekolah pada pemahaman dan penerimaan mereka terhadap DLP. Penelitian ini melibatkan 2162 siswa dan hasil penelitian menunjukkan bahwa tingkat pemahaman dan penerimaan mereka terhadap program ini berada pada tingkat yang cukup tinggi. Hasil penelitian ini juga menunjukkan perbedaan yang signifikan antara penerimaan program. Sebagai alternatif untuk meningkatkan penguasaan bahasa Inggris, implementasi DLP perlu ditingkatkan agar dapat diterima dengan baik oleh kelompok-kelompok yang berkepentingan.
\end{abstract}

\section{Kata Kunci: program Dwi Bahasa, siswa, pendidikan, penerimaan program}

\section{INTRODUCTION}

The choice of medium of instruction for an education system is critical and crucial in the education system, especially in the context of multi-ethnic countries, including Malaysia. In this light, the language used for the medium of instruction is has generated worldwide attention as it is linked to language policy and planning, as well as the management of schooling system. Furthermore, the role played by the medium of instruction significantly influences the performance of the education system. Studies have stipulated that medium of instruction has become a top-down phenomenon introduced by the policymakers and education managers to improve the quality of education (Belhiah \& Elhami 2015; Dearden 2014; Din \& Wing 2007; Tollefson \& Tsui 2018). Thus, attention should be given to language development programmes to address potential language-related challenges in classrooms with English as a medium of instruction (EMI) to ensure the quality of 
instruction (Margic \& Vodopija-Krstanović, 2018).

Numerous language-related programmes have been introduced, including teaching content subjects in English. Several countries have adopted the practice of teaching science and mathematics in English, such as South Africa (Mokiwa \& Msila, 2013; Mthiyane, 2016). Similarly, Fernandez-Sanjurjo, FernandezCostales, \& Blanco (2017); Karabay (2017); Mifsud \& Farrugia (2016) portrayed the use of English as the instructional medium for science and mathematics subjects. Most studies have focused on the competency of the teachers besides the use of bilingual strategy along with students' performance in the respective subjects. This trend reflects that the integration between language (English) and content subjects (science and mathematics) is affected by some hindrances.

This issue is also prominent in the Asian context where English proficiency tends to be higher in countries with historical ties to the language as countries colonised by European or American powers may have already used English in their education system. Education First (2016). Over the years, several Asian countries have imposed the use of EMI in science and mathematics as reflected in Racca \& Lasaten (2016); Lee, Watt \& Frawley (2015); Lin \& Wu (2015); Din \& Wing (2007). In this regard, here are different views pertaining the use English as the medium of instruction in teaching and learning the subjects. Such situation may also be prevalent in Malaysia.

At present, the Malaysia Ministry of Education (MOE) is implementing DualLanguage Programme (DLP) where science and mathematics are taught using the English language in selected schools. This programme for is optional and implemented only in certain schools which have fulfilled the criterion outlined by the MOE. Previously, the government has drastically introduced PPSMI (Pengajaran dan Pembelajaran Sains dan Matematik dalam Bahasa Inggeris) where English is made as the compulsory language of instruction for mathematics and science at all levels in primary and secondary education (Chan and Tan as cited in Sumintono, 2017). Hence, unlike the DLP, under PPSMI the MOE imposed that the teaching of science and mathematics is fully done in English. In regard to the DLP programme, while students were found to have moderate confidence, they showed that they are ready to learn using English despite the limitation in language mastery (Suliman, Nor, \& Yunus, 2017; 2018).

As English has become an indispensable tool to learn new knowledge and communicate, English proficiency is considered as a fundamental prerequisite for a developed country (Mohamad \& Zakaria, 2018; Aziz \& Nair, 2015). Therefore, learning science and mathematics in English creates an advantage as students are able to explore the knowledge globally. It also increases students' opportunities in the workforce (Suliman et al., 2017). Studies have found that many students found it comfortable and better to learn science and mathematics in English (Besar \& Jali, 2010; Probyn, 2015). The teaching and learning of science and mathematics using the English language is in tandem with the aspiration of the Malaysian Education Blueprint (2013-2025), to develop bilingual students who are proficient in Malay and English (Ministry of Education, 2015). This blueprint provides an avenue for students to learn the subjects through their preferred medium of instruction. The main aim is to enhance students' comprehension in their lessons irrespective of the language used.

There are various studies that have focused on the use of EMI. Lee et al. (2015) conducted a study in Cambodia and found that students in bilingual schools showed better performance in the mathematics subject compared to those studying in monolingual schools. On the other hand, Din and Wing (2007) examined 100 schools in Hong Kong and claimed that students struggled with learning science in English because they found it difficult to understand their teachers' instruction in the second language. This finding suggests that the use of EMI may exert negative effects on learning science. Other studies include Racca \& Lasaten (2016) in the Philippines and Otwinowska \& Forys (2015) in Poland.

In the Malaysian context, Sulaiman \& Konting (2014) compared the readiness of firstyear students in urban and rural areas to learn science in English. It was found that students in the urban area fare better than their counterparts in three major domains: communication, classification and observation. Another study by Norsyazwani, Akmal, Cheong, \& Singh (2013) 
revealed that $60 \%$ of 1311 students wanted to continue learning mathematics in English and $50 \%$ prefer to learn science in English. Meanwhile, Rice, Barth, Guadagno, Smith, \& McCallum (2013) argued that great peer support from parents, teachers and friends help students to display positive attitudes in learning these content subjects in English and help develop high perceptions of their science and mathematics abilities. Studies from Malaysia and other countries have revealed different findings, this indicates the need to study how students from different backgrounds and proficiency perceive the teaching and learning of science and mathematics in English. In this light, this study aims to examine sstudents' understanding and acceptance of the Dual Language Programme in Malaysian context. This study will examine the influence of four variables (age, gender, locality and type of school) on students' acceptance of the implementation of the DLP programme.

\section{METHOD}

This study is quantitative in nature and employed the survey research design with the use of questionnaire as the main research instrument.
The instrument was adapted from Ministry of Education Malaysia (2017) and Besar (2007). It was later amended to suit the context of this study. The first section contains six items in each dimension (acceptance and understanding), which enquire students' understanding and acceptance of the programme respectively. The items also probe on the students' demographic profile such as age, gender, locality and type of school. The questionnaire employed a fourpoint Likert-scale. The questionnaire contains twelve items. Several experts in the field were involved in validating he draft questionnaire and a pilot study was conducted. Reliability test was generated, and the Cronbach alpha value was .927 and .943 for both dimensions, which indicates the reliability of the instrument.

This study involved secondary schools who are involved in the DLP. According to the documents from the MOE, the population of the students for this study is 111135 , and the questionnaire was distributed to a sample of 2162 DLP students nationwide. These respondents were selected using multi-stage cluster sampling. Table 1 illustrates the demographic profile of the study's respondents.

Table 1. Respondents' Profile

\begin{tabular}{llr}
\hline Variable & Category & $\boldsymbol{N}(\mathbf{\%})$ \\
\hline Age & 14 & $1007(46.7 \%)$ \\
\multirow{3}{*}{ Gender } & 15 & $1148(53.1 \%)$ \\
& Male & $870(40.5 \%)$ \\
Locality & Female & $1280(59.5 \%)$ \\
& Urban & $1170(54.1 \%)$ \\
\multirow{2}{*}{ Type of school } & Nural & $992(45.9 \%)$ \\
& National Secondary School & $841(38.9 \%)$ \\
& Futional Religious Secondary School & $574(26.5 \%)$ \\
& Fully Residential School & $747(34.6 \%)$ \\
\hline
\end{tabular}

The data collection process took about five months to be completed. The researchers distributed the questionnaire to eighty secondary schools which participated in the DLP. The sets of were also distributed online through Google form. Upon receiving the completed questionnaires, the researcher conducted a preliminary analysis and unusable questionnaires were eliminated. The data analysis involved descriptive analysis and inferential statistics encompassing of $t$-test and one-way ANOVA. The use of these inferential statistics helps investigate the differences between the acceptance and understanding of DLP among students with different demographic profile.

\section{FINDINGS AND DISCUSSION}

Table 2 presents the mean scores for the items on respondents' understanding and acceptance of the DLP programme. 
Table 2. Understanding of the Programme

\begin{tabular}{lc}
\hline \multicolumn{1}{c}{ Item } & Mean \\
\hline DLP increases the learning interest in Science & 3.12 \\
DLP increases the learning interest in Mathematics & 3.18 \\
DLP increases the exposure to English in classroom & 3.56 \\
DLP strengthens English mastery & 3.58 \\
DLP eases students in getting the international level exposure & 3.45 \\
DLP broadens students' marketability in the employment sector & 3.59 \\
\hline
\end{tabular}

Based on the Table 2, students displayed a high level of understanding pertaining to the DLP implementation. The respondents ascertained that DLP would increase their marketability in the workforce besides strengthening their English mastery. Only a small number (around 4\%) refuted this claim. In addition, the respondents believe that DLP increases their exposure to the target language in the classroom, as well as their exposure towards science and mathematics resources out of the classroom. On the other hand, $18 \%$ of the respondents perceive that DLP is less likely to increase the interest in learning science and mathematics subjects.

Table 3 indicates that almost $96 \%$ of the respondents believe that DLP is good in enhancing English mastery. Following this, about 93\% respondents wanted for the programme to be improved. $88 \%$ respondents claimed that the programme is good to develop their science knowledge, whereas $87 \%$ affirmed that the implementation of DLP should be continued. Similarly, $87 \%$ opined that DLP could improve their mathematical skill. Last but not least, 79\% respondents illustrated their agreement that the programme is well-received by the students which contributed to the mean score of 3.01. The results indicate that respondents' acceptance towards the programme is on the positive level, with the total mean score of 3.30. Thus, the respondents are positive with the implementation of the programme.

Table 3. Acceptance towards the Programme

\begin{tabular}{lc}
\hline Item & Mean \\
\hline DLP is a good programme to increase English mastery & 3.58 \\
DLP is a good programme to develop science knowledge & 3.28 \\
DLP is a good programme to improve mathematics skill & 3.23 \\
DLP implementation is well-received by students & 3.01 \\
DLP implementation should be continued & 3.27 \\
DLP implementation should be improved & 3.43 \\
\hline
\end{tabular}

Inferential tests were also deployed to further examine the influence of the independent variable on the respondents' understanding and acceptance of the programme. Specifically, this study examined to what extend does the demographic factors influence the respondents' understanding and acceptance towards the programme. The result is presented in Table 4.

The Table 4 shows that out of four demographic factors, only age has no significant influence on students' understanding of the programme even though the younger respondents showed a more positive understanding of the programme. In the meantime, female respondents scored a higher mean score than the male respondents. It was also observed that respondents from the rural area has a more positive understanding than their counterparts in the urban area. In regards to the types of schools, respondents studying at fully residential schools obtained the highest mean score compared to those from national secondary schools and national religious secondary schools. 
Table 4. Inferential Tests Result for Understanding of DLP

\begin{tabular}{llccc}
\hline Variable & Category & Mean & SD & Sig. \\
\hline \multirow{2}{*}{ Age } & 14 & 3.42 & .46 & .262 \\
\multirow{3}{*}{ Gender } & 15 & 3.40 & .49 & \\
& Male & 3.35 & .50 & .000 \\
\multirow{2}{*}{ Locality } & Female & 3.46 & .45 & \\
& Urban & 3.38 & .49 & \multirow{2}{*}{.000} \\
Type of school & Rural & 3.45 & .46 & \\
& National Secondary School & 3.38 & .49 & \\
& National Religious Secondary School & 3.39 & .47 & .000 \\
& Fully Residential School & 3.47 & .46 & \\
\hline
\end{tabular}

As demonstrated in the Table 5, it is evident that age and locality has no effect on respondents' acceptance towards the programme. Despite the age difference, the respondents have scored the similar mean score. Meanwhile, the mean score of those in the rural area is slightly higher than those in the urban area. The results also show a significant difference between the acceptance of the programme among male and female students. Female students demonstrated a higher acceptance of DLP compared to male students with a mean score difference of .10 .

Table 5. Inferential Tests Result for Acceptance towards DLP

\begin{tabular}{llccc}
\hline Variable & Category & Mean & SD & Sig. \\
\hline \multirow{2}{*}{ Age } & 14 & 3.17 & .46 & \multirow{2}{*}{.967} \\
\multirow{3}{*}{ Gender } & 15 & 3.17 & .50 & \\
& Male & 3.11 & .51 & .000 \\
\multirow{3}{*}{ Locality } & Female & 3.21 & .45 & \\
& Urban & 3.16 & .50 & \multirow{2}{*}{.246} \\
\multirow{2}{*}{ Type of school } & Rural & 3.18 & .46 & \\
& National Secondary School & 3.20 & .48 & \\
& National Religious Secondary School & 3.09 & .49 & .000 \\
& Fully Residential School & 3.20 & .47 & \\
\hline
\end{tabular}

Another notable finding that the type of school has a significant effect on respondents' acceptance of the programme. The Scheffe post-hoc test was then conducted to identify the difference between groups. It was revealed that the acceptance towards the programme among students in national religious secondary school $(M=3.09, S D=.49)$ is significantly lower than students in national secondary school $(M=3.20$, $S D=.48)$ and fully residential school $(M=3.20$, $S D=.47)$. In this light, there is no significant difference between the acceptance towards the programme among the national secondary school students and fully residential school students.

The findings show that the respondents shared the similar views as represented in past studies (Ministry of Education Malaysia, 2017; US Department of Education, 2015). They believe the idea that this programme may boost their language development, and subsequently, increase their future potential in life. These findings are inter-related, as the ability to master the English would indirectly help promote future job marketability among the students. As elucidated by (Christian, 2016; Hamman, 2018; Thomas \& Collier, 2012), besides promoting academic excellence, DLP is also associated with bilingual education which will help students to become competent bilinguals in a multicultural setting. Hence, the respondents perceived that DLP could optimise their language development, aside from serving as the platform to increase their potential in the future job market.

An interesting finding is that the respondents affirmed that DLP would less likely to increase students' interest in learning science 
and mathematics. This implies that DLP have higher benefit on language development than the learning of content subjects. Studies have also indicated that STEM field is less favoured by the students and there is a growing negative attitude towards learning science and mathematics (Kiemer, Groschner, Pehmer, \& Seidel, 2015; Rice et al., 2013; Sunyoung, 2017). This calls for a serious consideration by the Ministry of Education in order to achieve the ratio of 60:40 in the number of students enrolled in the science stream and arts stream. Another growing concern in regard to the STEM performance is the high competition in the workforce (Bean, Gnadt, Maupin, White, \& Anderson, 2016; Ling, Lee \& Jiebo, 2016). Thus, the move to solidify English is a propitious one but there are some hindrances that need be overcome when making English the instructional medium in the teaching and learning of content subjects, specifically Mathematics and Science.

These results revealed that the respondents are positive towards the programme because they believe that DLP assists them to cultivate and increase their English mastery. This replicates that the essential need to be proficient and competent in English especially as globalisation has increased the use of English (Hugo, 2018). Furthermore, the respondents agree that when they are more proficient in English, there is a higher chance for them to perform better in the content subjects (Racca \& Lasaten, 2016). The respondents also perceive that the implementation of the programme needs to be improved. This may be due to some loopholes encountered by the respondents in the programme implementation. Improvement is inevitable as many issues were raised in past studies pertaining to the use of English as the instructional medium in teaching science and mathematics. Furthermore, there is a need to address potential language-related challenges in EMI classrooms and ensure the quality of instruction (Margic \& Vodopija-Krstanović, 2018). This somehow leads to low mean score for item 'DLP is well-received by the students'. It could be argued that if certain aspects or elements of implementation are rectified, students might have better acceptance towards the programme. Hence, serious consideration is needed in ameliorating the current state of DLP implementation.
The findings show that school location could have a significant effect on students' performance and highlights the disparity between students' performance in the urban and rural context (Gobel, Thang, Sidhu, Oon, \& Chan, 2013; Olutola, 2016). Interestingly, students from the rural area displayed a more positive understanding than those in the urban area. This refutes the Ministry of Education Malaysia (2015) report that students in the urban area are on the upper hand than those in the rural area during the implementation of PPSMI. The lack of English language proficiency remains an issue that contributes to the achievement gap between students in the urban and rural area (Ministry of Education 2018). This reinforces the persistent achievement gap in the educational attainment between students where those with access to the language of instruction in their home context will have more advantage, as alluded by Kalinowski, Egert, Gronostaj \& Vock (2020). It could be argued that students in the urban areas will perform better as they are more inclined towards using English in learning science and mathematics. This confirms the report by the Ministry of Education Malaysia (2015) that the learning situation differs for students coming from national and national-type schools, as well as those in the rural and urban area schools.

The inferential test results elucidated that age and locality have no effect in the context of this study. However, it is interesting to note that rural area respondents demonstrated a better acceptance of the programme in comparison to their counterparts the urban area. Perhaps, the cognisance on this programme has developed more positive acceptance among students in the rural area students. In a similar vein, female students showed more positive acceptance of the programme compared to male students. This may be due to the fact that female students have higher awareness of the benefits of learning English or because they are more motivated instrumentally than the males (Gardner \& Lambert, 1959). Moreover, Yaman said that females have high inclination towards learning English and other languages besides other academic subjects for the progression of their future career (Abdullah, Ong \& Ariffin, 2013).

Another notable finding is that the level of DLP acceptance differs across students from different types of schools. In this light, 
students from fully residential school are more homogenous in comparison to students from national secondary schools, hence, they might have set certain standard or target for them to accomplish. This could indirectly affect their acceptance towards the programme. Students from national secondary schools are least interested in learning the two subjects in English as acclaimed by Besar (2007). In regard to this finding, it will be interesting to examine whether the different learning environment in these three types of school may contribute to the students' acceptance of DLP.

\section{CONCLUSION}

This study has shown that the respondents demonstrated a positive and high level of acceptance towards the implementation of the Dual Language Programme. This study also found a significant difference between the understanding and acceptance of DLP among students with different gender and from different types of school while age and locality has no or little influence. Thus, future studies could examine whether students' positive acceptance towards DLP sparks from positive learning environment, which could improve their learning process. Moreover, as mentioned, the difference in terms of locality and type of school should not be a hindrance towards DLP implementation.

Based on the finding, there is a need for DLP implementation to be improved to provide students with a more conducive learning environment. It is also proposed for future research to undertake a different research paradigm instead of focusing solely on the positivism approach. Interviews and classroom observations could be conducted in the future to further examine the two variables studied.

In this light, irrefutably, improving standard of English is one of the main agenda of DLP. However, it takes more efforts to ensure the success of its implementation. This study believes that DLP could be successful if certain aspects of its implementation are rectified and solidified to cater to the needs of the students involved in the programme.

\section{ACKNOWLEDGEMENT}

This work is funded by the Faculty of Education, Universiti Kebangsaan Malaysia grant GG-2019-032.

\section{REFERENCES}

Abdullah, M. R. T., Ong, H. L., \& Ariffin, Z. Z. (2013). Gender and beliefs in learning English at the National Defence University of Malaysia. Proceeding of $5^{\text {th }}$ International Conference on Humanities and Social Sciences, pp. 252-262. http:// fs.libarts.psu.ac.th/research/conference/ proceedings-5/3.5-Gender\%20and $\% 20$ Beliefs \% 20 in $\% 20$ Learning $\% 20$ English\%20at\%20the\%20National\%20 Defence $\% 20$ University $\% 20$ of $\% 20$ Malaysia.pdf.

Aziz, R.M.R.A., \& Nair, R.(2015). Globalisation and the evolution of English Language Education in Malaysian secondary schools. In Spolsky, B. \& Sung, K. (Eds.), Secondary school English Education in Asia. New York, NY: Routledge, pp. 148158.

Belhiah, H., \& Elhami, M. (2015). English as a medium of instruction in the Gulf: When students and teachers speak. Language Policy 14(1), 3-23. https://doi.org/ 10.1007/s10993-014-9336-9.

Bean, N., Gnadt, A., Maupin, N., White, S. A. \& Anderson, L. (2016). Mind the gap: Student researchers use secondary data to explore disparities in STEM education. Prairie Journal of Educational Research, 1(1), 31-54. https://doi.org/10.4148/23730994.1002 .

Besar, J. A. (2007). The policy of teaching and learning science and mathematics in English: Impact study in Selangor and Terengganu. (Unpublished Masters Dissertation, Universiti Kebangsaan Malaysia).

Besar, J. A., \& Jali, F. M. (2010). Pemansuhan Dasar PPSMI: Tinjauan daripada perspektif parti politik, ahli akademik dan NGO serta pengalaman di sekolah. [The abolishment of PPSMI policy: A survey from the political parties, academicians, NGO and experience in schools]. Jurnal Melayu, 5(2010), 177-197. http://ejournal. ukm.my/jmelayu/article/view/4952/2509.

Christian, D. (2016). Dual language education: 
Current research perspectives. International Multilingual Research Journal, 10(1), 1-5. https://doi.org/10.10 80/19313152.2016.1118666.

Dearden, J. (2014). English as a medium of instruction: A growing phenomenon. Oxford, OX: British Council. https://doi. org/10.13140/RG.2.2.12079.94888.

Din, Y. Y., \& Wing, K. T. (2007). Evaluation of the effects of the medium of instruction on science learning of Hong Kong secondary students: Students' self-concept in Science. International Journal of Science and Mathematics, 27(2), 295-331. https:// doi.org/10.1080/15235882.2003.101628 08 .

Education First. (2016). EF English proficiency index. www.ef.com/epi.

Fernandez-Sanjurjo, J., Fernandez-Costales, A., \& Blanco, J. M. A. (2017). Analysing students' content-learning in Science in CLIL vs non CLIL programmes: Empirical evidence from Spain. International Journal of Bilingual Education and Bilingualism, 22(6), 661-674. https://doi. org/10.1080/13670050.2017.1294142.

Gardner, R. C., \& Lambert, W. E. (1959). Motivational variables in second language acquisition. Canadian Journal of Psychology, 13(4), 266-272. https://doi. org/10.1037/h0083787.

Gobel, P., Thang, S. M., Sidhu, G. K., Oon, S. I., \& Chan, Y. F. (2013). Attributions to success and failure in English language learning: A comparative study of urban and rural undergraduates in Malaysia. Asian Social Science, 9(2), 53-62. https:// doi.org/10.5539/ass.v9n2p53.

Hamman, L. (2018). Translanguaging and positioning in two-way dual language classrooms: A case for criticality. Language and Education, 32(1), 21-42. https://doi.org/10.1080/09500782.2017.1 384006.

Hugo, Y. H. L. (2018). The effect of multicultural family structures on the language attitudes of children and adolescents. GEMA Online Journal of Language Studies, 18(1), 122-139. https://doi.org/10.17576/ gema-2018-1801-08.

Kalinowski, E., Egert, F., Gronostaj, A. \& Vock, M. (2020). Professional development on fostering students' academic language proficiency across the curriculum: A metaanalysis of its impact on teachers' cognition and teaching practices. Teaching and Teacher Education, 88, 102971. https:// doi.org/10.1016/j.tate.2019.102971.

Karabay, A. (2017). STEM and social sciences students' language oriented academic challenges in English medium of instruction programs: The case of International University in Kazakhstan. (Unpublished Masters Dissertation, Nazarbayev University).

Kiemer, K., Groschner, A., Pehmer, A. \& Seidel, T. (2015). Effects of a classroom discourse intervention on teachers' practice and students' motivation to learn mathematics and science. Learning and Instruction, 35(2015), 94-103. https://doi. org/10.1016/j.learninstruc.2014.10.003.

Lee, S., Watt, R., \& Frawley, J. (2015). Effectiveness of Bilingual Education in Cambodia: A longitudinal comparative case study of ethnic minority children in bilingual and monolingual schools. Compare, 45(4), 526-544. https://doi.org/ 10.1080/03057925.2014.909717.

Lin, A. M. Y., \& Wu, Y. (2015). May I speak Cantonese? Constructing a scientific proof in an EFL junior secondary science classroom. International Journal of Bilingual Education and Bilingualism, 18(3), 289-305. https://doi.org/10.1080/1 3670050.2014 .988113 .

Ling, H., Lee, M. \& Jiebo, L. (2016). Using social media to promote STEM education: Matching college students with role models. Joint European Conference on Machine Learning. https://arxiv.org/ abs/1607.00405.

Margic, B. D., \& Vodopija-Krstanović, I. 
(2018). Development of English-medium instruction: Teachers' perceptions, reflections and learning. Journal of English for Academic Purposes, 35, 31-41. https:// doi.org/10.1016/j.jeap.2018.06.005.

Mifsud, J., \& Farrugia, J. (2016). Language choice for Science Education: Policy and practice. The Curriculum Journal, 28(1), 83-104. https://doi.org/10.1080/0958517 6.2016 .1251847

Ministry of Education Malaysia. (2018). Malaysian education blueprint 2017 annual report. Putrajaya: Kementerian Pendidikan Malaysia.

Ministry of Education Malaysia. (2017). Kajian pelaksanaan DLP dan HIP. [DLP and HIP implementation study]. Putrajaya: Kementerian Pendidikan Malaysia.

Ministry of Education Malaysia. (2015). The English language roadmap 2015 - 2025. Putrajaya: Kementerian Pendidikan Malaysia.

Mohamad, M., \& Zakaria, N. Y. K. (2018). Development of English language camp: Reception and perception of Asnaf pupils in Malaysia. Global Journal AlThaqafah, 8(2), 31-44. http://www.gjat. my/gjat122018/GJAT122018-3.pdf.

Mokiwa, H. O., \& Msila, V. (2013). Teachers' conceptions of teaching physical science in the medium of English: A case study. International Journal of Educational Sciences, 5(1), 55-62. https://doi.org/10. 1080/09751122.2013.11890061.

Mthiyane, N. (2016). Pre-service teachers' beliefs and experiences surrounding the use of language in science classrooms: A South African case study. Nordic Journal of African Studies, 25(2), 111-129. https:// njas.fi/njas/article/view/112.

Norsyazwani, R., Akmal, N. Cheong, T. H., \& Singh, P. (2013). Unleashing students and teachers' voice and choice in the learning of Mathematics and Science. Procedia Social and Behavioral Sciences, 90(2013), 530-539. https://doi.org/10.1016/j. sbspro.2013.07.123.

Olutola, A. T. (2016). School location and gender as predictors of students' performance in WASSCE multiple choice test in biology. Asian Scientific Journal, 12(1), 1-16. https://doi.org/10.7828/1jher.v12i1.960.

Otwinowska, A., \& Forys, M. (2015). They learn the CLIL way but do they like it? Affectivity and cognition in upper-primary CLIL classes. International Journal of Bilingual Education and Bilingualism, 20(5), 1-32. https://doi.org/10.1080/1367 0050.2015 .1051944 .

Probyn, M. (2015). Pedagogical translanguaging: Bridging discourses in South African science classrooms. Language and Education, 29(3), 218-234. https://doi.or $\mathrm{g} / 10.1080 / 09500782.2014 .994525$.

Racca, R. M. A. B., \& Lasaten, R. C. S. (2016). English language proficiency and academic performance of Philippines science high school students. International Journal of Languages, Literature and Linguistics, 2(2), 44-49. https://doi.org/10.18178/ ij111.2016.2.2.65.

Rice, L., Barth, J. M., Guadagno, R. E., Smith, G. P. A., \& McCallum, D. M. (2013). The role of social support in students' perceived abilities and attitudes toward Math and Science. Journal of Youth Adolescence, 42(7), 1028-1040. https:// doi.org/10.1007/s10964-012-9801-8.

Sulaiman, T., \& Konting, M. M. (2014). Kesediaan murid Tahun 1 mengikuti pengajaran kemahiran proses sains dalam Bahasa Inggeris [The primary 1 students' readiness in adapting to science process skills teaching in English]. Jurnal Kepimpinan Pendidikan, 1(1), 1-6. https:// jupidi.um.edu.my/article/view/8281.

Sumintono, B. (2017). Science education in Malaysia: Challenges in the $21^{\text {st }}$ Century. Cakrawala Pendidikan, 36(3), 459-471. https://doi.org/10.21831/cp.v36i3.16761.

Suliman, A., Nor, M. Y. M. \& Yunus, M. M. (2017). Dual language programme in 
Malaysian secondary schools: Glancing through the students' readiness and unravelling the unheard voices. GEMA Online Journal of Language Studies, 17(4), 128-145. https://doi.org/10.17576/ gema-2017-1704-09.

Suliman, A., Nor, M. Y. M. \& Yunus, M. M. (2018). Gleaning into students' perspectives in learning Science and Mathematics using the English language. The Journal of Social Sciences Research, 2, 445-456. https://doi.org/10.32861/jssr. spi2.445.456.

Sunyoung, H. (2017). Korean students' attitudes toward STEM project-based learning and major selection. Educational Sciences:
Theory \& Practice, 17(2), 529-548. https:// doi.org/10.12738/estp.2017.2.0264.

Thomas, W. P., \& Collier, V. P. (2012). Dual language education for a transformed world. Albuquerque: Fuente Press.

Tollefson, J. W. \& Tsui, A. B. M. (2018). Medium of instruction policy. In Tollefson, J. W. \& Perez-Milans, M. (Eds.), Language policy and planning. New York, NY: Oxford University Press.

US Department of Education. (2015). Dual language education programme: Current state policies and practices. Washington DC: American Institutes for Research. 